\title{
EVALUATION OF ANTIPROLIFERATIVE AND HEPATOPROTECTIVE EFFECTS OF WHEAT GRASS (TRITICUM AESTIVUM)
}

\author{
Anand Rajoria, ${ }^{1}$ Archana Mehta, ${ }^{1}$ Pradeep Mehta, ${ }^{1}$ LaXmi Ahirwal, ${ }^{1}$ \\ SHRUTI SHUKLA ${ }^{2 *}$ and ViveK K. BAJPAI ${ }^{3 *}$ \\ ${ }^{1}$ Laboratory of Plant Pathology and Microbiology, Department of Botany, \\ Dr. Hari Singh Gour University, Sagar 470003 MP, India \\ ${ }^{2}$ Department of Energy and Materials Engineering, Dongguk University, Seoul, \\ 30 Pildong-ro 1-gil, Seoul 04620, Republic of Korea \\ 32Department of Applied Microbiology and Biotechnology, School of Biotechnology, \\ Yeungnam University, Gyeongsan, Gyeongbuk 712-749, Republic of Korea
}

(Received: October 4, 2016; accepted: January 28, 2017)

\begin{abstract}
This study was aimed to evaluate the pharmacological potential of various extracts (hexane, chloroform, methanol and aqueous) of dried shoots of Triticum aestivum (wheat grass) in terms of antiproliferative and hepatoprotective potential of T. aestivum. The total chlorophyll content in dried shoots of T. aestivum was $0.54 \pm 0.016 \mathrm{~g} / \mathrm{L}$ (chlorophyll-a: $0.288 \pm 0.05 \mathrm{~g} / \mathrm{L}$; and chlorophyll-b; $0.305 \pm 0.05 \mathrm{~g} / \mathrm{L}$ ), while total carotene content was $0.42 \pm 0.066 \mathrm{~g} / \mathrm{L}$. In addition, the chloroform extract of dried shoots of T. aestivum $(250 \mu \mathrm{g} / \mathrm{mL})$ exhibited $87.23 \%$ inhibitory effect with potent cytotoxicity against human hepatocellular carcinoma (HepG2) cancer cell line. Moreover, chloroform and methanol extracts significantly reduced the levels of SGOT, and SGPT enzymes, as well as total bilirubin content, while raised the level of total protein in a concentration-gradient manner, confirming the potent hepatoprotective effect of $T$. aestivum. A possible mechanism of apoptosis of the chloroform extract of dried shoots of $T$. aestivum in terms of its potent antiproliferative activity against HepG2 cancer cell line can also be proposed in this study. Our findings clearly demonstrate that $T$. aestivum has a significant pharmacological potential that night be used for antiproliferative and hepatoprotective purposes.
\end{abstract}

Keywords: T. aestivum (wheat grass) - antiproliferative - hepatoprotective - apoptosis mechanism - pharmacological significance

\section{INTRODUCTION}

Triticum aestivum Linn. (wheat grass) belonging to the Gramineae family, is widely cultivated almost all over the world [18]. Wheat grass stimulates metabolism and restores alkalinity in the blood, which helps to reduce acidity in the blood and to restore healthy cells along with an ability to serve as a detoxificant agent [18]. Reactive oxygen species (ROS) are produced as by-products of various metabolic processes, mainly during respiration in living organisms. Consequently, oxidative stress is considered to be implicated in the pathophysiology of many diseases including cancer [2].

Various medicinal herbs have been used as a treatment for various ailments, including malignancies [10]. Human hepatocellular carcinoma (HCC) is one of the

*Corresponding authors; e-mail addresses: shruti.shukla15@yahoo.com; vbajpai04@ynu.ac.kr 
most common malignancies worldwide with an annual incidence of approximately 600,000 cases, including 55\% in China [19]. Hence, patients suffering from HCC often turn to use natural treatment, largely based on the use of traditional medicinal plants. Indeed, some medicinal plant extracts have shown to display antiproliferative activities on different HCC cell lines [5].

The liver is the most important and integral part of both human and animal body system, and is highly affected primarily by toxic agents [16]. In addition, consuming large amount of drugs, intake of alcohol, and junk food is also endangering the functional ability of the liver by damaging the liver architecture. Though allopathic drugs are available, they do not represent a complete solution. However, medicinally important plants are capable of targeting these hepatic disorders because a number of plants having medicinal properties have been investigated based on the integrative approaches on drug development against liver diseases [14].

Plant extracts containing high concentration of chlorophylls and carotenoids are of significant importance because they can exhibit different protective effects by excerting different mechanisms [4]. The consumption of carotenoids and chlorophylls has been associated with protective effects against atherosclerosis, some forms of cancer, osteoporosis, cataracts, neurodegenerative diseases, mutagenesis, and oxidative stress [8]. The protective effects of carotenoids are mediated by their oxidant, antioxidant, redox sensitive cell signalling, induction of gene expression, and provitamin A properties [7]. The protective effects of chlorophylls depend on their ability to modulate the activation of the endogenous xenobiotic detoxification systems and caspases/polymerase pathway as well as by their antioxidant and mutagen trapping properties [4]. Chlorophyll and carotenoid compounds have shown enormous hepatoprotective effects via several mechanisms, which include lowering the levels of lipid peroxidation and increasing the activity of the antioxidant enzyme superoxide dismutase (SOD) [13].

Although some preliminary studies on Triticum aestivum (wheat grass) have been reported [18], no detailed and systematic information on antiproliferative and hepatoprotective potential of T. aestivum has been published so far. Hence, the present study was aimed to evaluate antiproliferative and hepatoprotective potential of various extracts derived from the dried shoots of T. aestivum maintained under specified growth conditions.

\section{MATERIAL AND METHODS}

\section{Reagents and chemicals}

Folin-Ciocalteu's reagent, 2,2-Diphenyl-1-picrylhydrazyl (DPPH), gallic acid, quercetin, potassium ferricyanide, ferric chloride, ascorbic acid, pyrogallol, mushroom tyrosinase, 3,4-dihydroxy-L-phenylalanine (DOPA), bovine serum albumin, P-nitrophenyl-a-D-glucopyranoside, aluminium chloride, sodium carbonate, hydrochloric acid, trypsin, ethylene diamine tetra acetic acid (EDTA), dimethyl sulphoxide 
(DMSO), MTT dye, Liv-52 and ethyl acetate were purchased from Sigma-Aldrich (St. Louis, MO, USA). Trichloroacetic acid (TCA) was obtained from Wako Pure Chemical Industries (Japan). Ferric chloride was purchased from Fluka (Steinhiem, Switzerland).

\section{Plant material}

The seeds of T. aestivum were collected from the Regional Agriculture Research Institute (RARI, India) in sterile polythene bags and were authenticated by a senior scientist of the institute. A voucher specimen has been deposited in the laboratory of RARI, India.

\section{Growth conditions}

The seeds of T. aestivum were sown during September, 2015, when the climatic conditions were suitable for the growth of wheat grass. Six plots of $1 \mathrm{~m}^{2}$ were prepared for sowing in the Botanical garden, RARI, India. Loamy soil ( $70 \%$ sand $+30 \%$ clay) was prepared and conditioned with compost. The $\mathrm{pH}$ of the soil was optimized from 6.9-7.2, whereas germination temperature was maintained in the range of $16-21{ }^{\circ} \mathrm{C}$, the optimum growth temperature for wheat grass. The seeds were soaked in water before sowing for $12 \mathrm{~h}$ at room temperature. The plants watered in alternative days and harvested on the $10^{\text {th }}$ day.

\section{Preparation of organic extracts}

The powdered form of dried shoots of T. aestivum (10 g) was successively extracted with $100 \mathrm{~mL}$ of each solvent, including methanol, hexane, chloroform, and distilled water, using a orbital shaker for $48 \mathrm{~h}$ at $37^{\circ} \mathrm{C}$. After $48 \mathrm{~h}$, the supernatant was filtered and evaporated to dryness to give a viscous dark mass with a percentage yield of $1.65 \%, 0.88 \%, 9.8 \%$ and $12.41 \%(\mathrm{w} / \mathrm{w})$, respectively. These dried crude extracts of T. aestivum were dissolved in water or the suitable solvent ( $1 \%$ DMSO), and used for the assessment of pharmacological activities.

\section{Experimental animals}

For our experiments adult Wistar albino rats of both sexes, weighing between 140$160 \mathrm{~g}$ body-weight were used. The experiments received an animal ethics approval from the institutional ethical committee via 1030/9/07/CPCSEA. 


\section{Acute toxicity assay}

For acute toxicity assay, rats of both sexes were divided into different groups. After an overnight fasting, extracts of dried shoots of $T$. aestivum were administered orally in a dose range of $100-500 \mathrm{mg} / \mathrm{kg}$ body weight of each animal, following a continuous observation for the next $2 \mathrm{~h}$ for any toxicity or disease symptom, and for mortality up to $24 \mathrm{~h} \mathrm{[1]}$.

\section{Estimation of total chlorophyll (chlorophyll-a, chlorophyll-b) and carotene contents}

Total chlorophyll (chlorophyll-a, and chlorophyll-b) and carotene contents in the extracts of dried shoots of T. aestivum were determined according to the method of Jayaraman [9]. Briefly, $1 \mathrm{~g}$ of dried shoot-leaf sample of T. aestivum was grinded in pestle-mortar with $5 \mathrm{~mL}$ of distilled water to form a paste. The contents were transferred to a centrifuge tube and the total volume was made up to $10 \mathrm{~mL}$ with distilled water. A $0.5 \mathrm{~mL}$ of supernatant from the tube was transferred to a fresh tube containing $4.5 \mathrm{~mL}$ of $80 \%$ acetone. The contents were centrifuged at $4,000 \times \mathrm{g}$ for $15 \mathrm{~min}$. The absorbance of the supernatant was calculated to measure total contents of chlorophyll (chlorophyll-a, chlorophyll-b) and carotene (co-efficient 2500) at the wavelengths of $661.5,645$, and $450 \mathrm{~nm}$, respectively, using following formulas:

$$
\begin{aligned}
& \text { Chlorophyll-a content }(\mu \mathrm{g} / \mathrm{mL})=11.24 \times \mathrm{A}_{661.5}=2.04 \times \mathrm{A}_{645.0} \\
& \text { Chlorophyll-b content }(\mu \mathrm{g} / \mathrm{mL})=20.13 \times \mathrm{A}_{645.0}=4.19 \times \mathrm{A}_{661.5}
\end{aligned}
$$

Carotenoid content $(\mathrm{mg} / \mathrm{mL})=\left(\mathrm{A}_{450.0} \times\right.$ Volume of sample taken $) / 2500$.

\section{Determination of antiproliferative activity against human hepatocellular carcinoma cells}

To evaluate the antiproliferative activity of various extracts of dried shoots of $T$. aestivum, MTT assay was used with Hep G2 (human hepatocellular carcinoma) cells, according to the modified method of Yin et al. [20]. A 90\% confluent Hep G2 cells were trypsinized, counted and prepared in a suspension with $10^{4}$ cells in $100 \mu \mathrm{L}$ of DMEM (Dulbecco's Modified Eagle Media) and seeded in a 24 wells plate. Each extract of T. aestivum was dissolved in $1 \%$ DMSO and different concentrations (25, $50,100,150,200$ and $250 \mu \mathrm{g} / \mathrm{mL}$ ) were prepared, and added to the wells along with the HEp-G2 cells. Treated cells were incubated at $37^{\circ} \mathrm{C}$ in a humidified atmosphere for $24 \mathrm{~h}$. Media was withdrawn and washed with fresh media $(300 \mu \mathrm{L})$ and then microscopy was performed. Before and after the treatment, the cells were morphologically analyzed. Each concentration was tested in triplicates. Untreated cells were used as a negative control. After $24 \mathrm{~h}, 50 \mu \mathrm{L}$ of MTT ( $2 \mathrm{mg} / \mathrm{mL}$ in PBS) was added 
to each well, incubated for an additional $4 \mathrm{~h}$, and the plate was centrifuged at $1,000 \times \mathrm{g}$ for $10 \mathrm{~min}$. The media was removed and $100 \mu \mathrm{L}$ of DMSO was added, dissolved and optical density (OD) was taken immediately at $570 \mathrm{~nm}$ by a microplate reader. The $\%$ inhibition was calculated using the following formula:

Inhibition $(\%)=$ Control OD - Sample OD/Control OD $\times 100$

\section{Determination of hepatoprotective activity}

Based on the effective antiproliferative results, chloroform and methanol extracts of dried shoots of T. aestivum were chosen for further evaluation of hepatoprotective activity. A total of 36 animals were divided into 6 groups ( $n=6$ in each group). The treatment period was 6 days. Group I served as a control and received normal saline $(10 \mathrm{~mL} / \mathrm{kg} \mathrm{p.o})$. Group II received $\mathrm{CCl}_{4}(50 \mu \mathrm{L} / \mathrm{kg}$ b.w.) diluted with liquid paraffin (1:1) given orally on $3^{\text {rd }}$ and $6^{\text {th }}$ day, Group III received $\mathrm{CCl}_{4}$ and standard drug Liv$52\left(50 \mathrm{mg} / \mathrm{kg}\right.$ b.w., p.o.). Similarly, Groups IV and $\mathrm{V}$ received $\mathrm{CCl}_{4}$ and chloroform and methanol extracts at different concentrations $(50,100$ and $200 \mathrm{mg} / \mathrm{kg}$ ) once daily simultaneously for 7 days. Food was withdrawn $12 \mathrm{~h}$ before $\mathrm{CCl}_{4}$ administration on the $6^{\text {th }}$ day to enhance the acute liver damage in all the groups, except group I animals (control). Rats were sacrificed on $7^{\text {th }}$ day, $24 \mathrm{~h}$ after administration of the last dose. Blood samples were collected by the abdominal aorta method in standard sampling tubes and serum was separated within $8 \mathrm{~h}$ at room temperature for use of assay marker enzymes and estimation of total protein.

\section{Enzyme assays}

The activities of serum hepatic marker enzymes such as serum glutamic pyruvic transaminase (SGPT) and serum glutamic oxaloacetic transaminase (SGOT) were assayed using standard kits from Merck (Germany). The results were expressed as units/liter $(\mathrm{U} / \mathrm{L})$. The data obtained were subjected to statistical analysis.

\section{Estimation of total serum protein and bilirubin}

The level of total serum protein and bilirubin were estimated by Biuret method [15] and according to the developed protocol of Maekawa et al. [11].

\section{Statistical data analysis}

Statistical analysis was performed using an SPSS software followed by multiple Duncan's test with analysis of variance (ANOVA) to find out the significant difference at $\mathrm{p}<0.05$ for each parameter. 


\section{RESULTS}

\section{Total chlorophyll (chlorophyll-a, chlorophyll-b) and carotene contents}

The dried leaf-shoots of T. aestivum were subjected to estimate total chlorophyll (chlorophyll-a and chlorophyll-b) and carotene contents. The total chlorophyll in the dried leaf-shoots of $T$. aestivum was found to be $0.54 \pm 0.016 \mathrm{~g} / \mathrm{L}$, out of which, amounts of chlorophyll-a, and chlorophyll-b were found as $0.288 \pm 0.05$ and $0.305 \pm 0.05 \mathrm{~g} / \mathrm{L}$, respectively. The total carotene content was measured as $0.42 \pm$ $0.066 \mathrm{~g} / \mathrm{L}$.

\section{Antiproliferative activity against human hepatocellular carcinoma cells}

The results showed that the chloroform extract of dried shoots of T. aestivum had a remarkable antiproliferative effect with $\mathrm{IC}_{50}$ value of 87.64. The absorbance values shown by the chloroform extract were $0.178 \pm 0.01,0.156 \pm 0.02,0.110 \pm 0.01$, $0.088 \pm 0.02,0.069 \pm 0.02$ and $0.054 \pm 0.21$, indicating the percentage inhibition of $16.54 \pm 1.67,30.34 \pm 3.14,56.18 \pm 1.98,68.54 \pm 2.76,79.22 \pm 4.87$ and $87.64 \pm 6.07$ at the concentration of $25,50,100,150,200$ and $250 \mu \mathrm{g} / \mathrm{mL}$, respectively (Table 1 , Fig. 1A). DMEM and DMSO in a ratio of 1:1 were used as a control, and their OD value was 0.423 at $570 \mathrm{~nm}$. A dose-dependent response on antiproliferative activity was observed when tested the chloroform extract of dried shoots of T. aestivum. Decrease in OD values of the cells represents the increase in percentage inhibition of the cancerous cells (Fig. 1B). At the highest concentration $(250 \mu \mathrm{g} / \mathrm{mL})$, the chloroform extract showed $87.64 \pm 6.07 \%$ inhibition of the cancerous cells.

Table 1

Antiproliferative activity of chloroform extracts $T$. aestivum

\begin{tabular}{|c|c|c|c|}
\hline \multirow{2}{*}{$\begin{array}{c}\text { Concentration } \\
(\mu \mathrm{g} / \mathrm{mL})\end{array}$} & Absorbance & $\%$ viability & $\%$ inhibition \\
\cline { 2 - 4 } & $0.178 \pm 0.01^{\mathrm{a}}$ & $83.46 \pm 1.87^{\mathrm{a}}$ & $16.54 \pm 1.67^{\mathrm{f}}$ \\
\hline 25 & $0.156 \pm 0.02^{\mathrm{ab}}$ & $69.66 \pm 3.45^{\mathrm{b}}$ & $30.34 \pm 3.14^{\mathrm{e}}$ \\
\hline 50 & $0.110 \pm 0.01^{\mathrm{b}}$ & $43.82 \pm 5.98^{\mathrm{c}}$ & $56.18 \pm 1.98^{\mathrm{d}}$ \\
\hline 100 & $0.088 \pm 0.02^{\mathrm{c}}$ & $31.46 \pm 6.97^{\mathrm{d}}$ & $68.54 \pm 2.76^{\mathrm{c}}$ \\
\hline 150 & $0.069 \pm 0.02^{\mathrm{d}}$ & $20.78 \pm 3.45^{\mathrm{e}}$ & $79.22 \pm 4.87^{\mathrm{b}}$ \\
\hline 200 & $0.054 \pm 0.02^{\mathrm{e}}$ & $12.36 \pm 2.52^{\mathrm{f}}$ & $87.64 \pm 6.07^{\mathrm{a}}$ \\
\hline 250 &
\end{tabular}

Superscripts in the same line not sharing a common superscript are significantly different at $\mathrm{p}<0.05$ by Duncan's multiple range test while, Superscripts sharing a common letter in the same line are not significantly different at $\mathrm{p}<0.05$ by Duncan's multiple range test. 


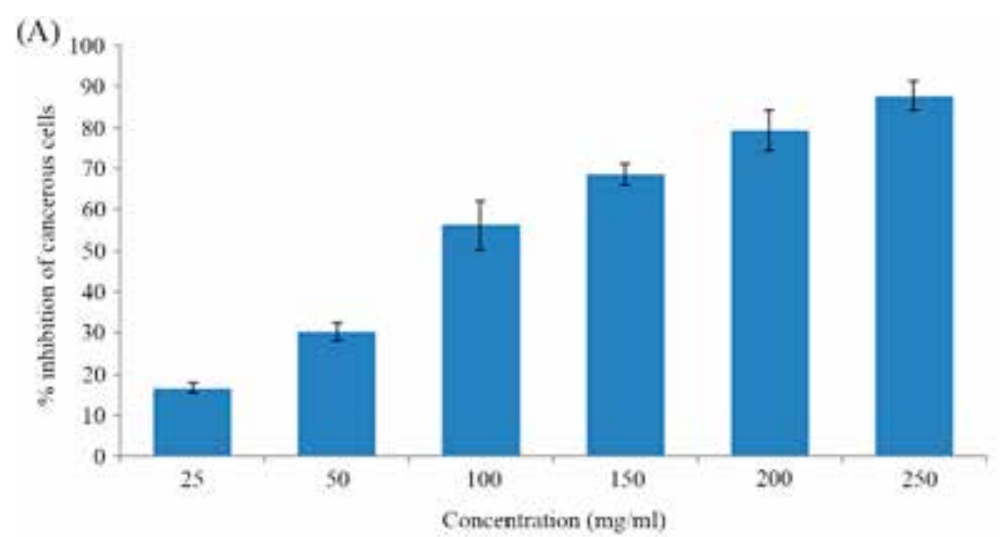

Fig. 1A. Effect of chloroform extract of dried shoots of T. aestivum on percent inhibition of human hepatocellular carcinoma (HepG2) cancer cell lines in MTT assay. All values are mean \pm S.D., $p<0.05$ significant
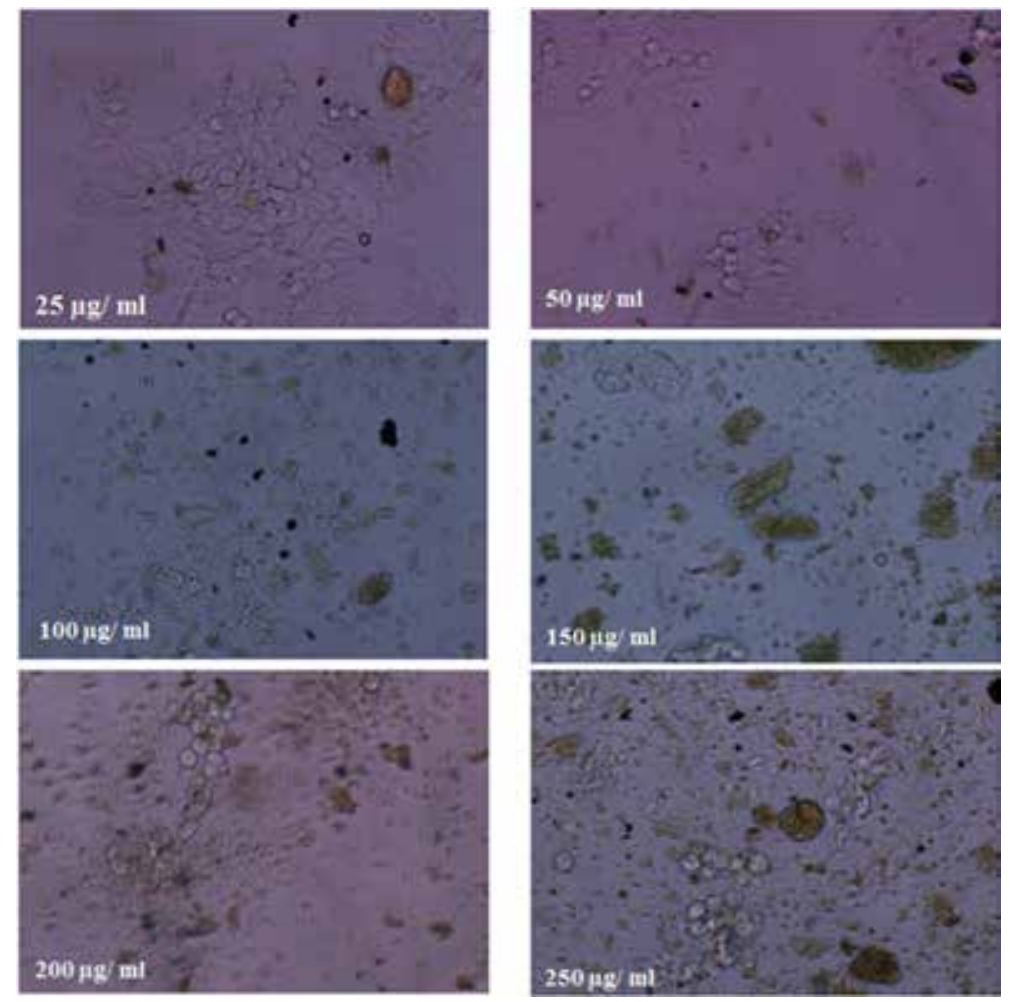

Fig. 1B. Antiproliferative potency of chloroform extract of dried shoots of T. aestivum at various concentrations against human hepatocellular carcinoma (HepG2) cancer cell lines 


\section{Hepatoprotective activity}

Based on effectiveness of chloroform and methanol extracts of dried shoots of T. aestivum observed in various in vitro antioxidant assays (data not shown), in vivo hepatoprotective activity of both the extracts was investigated using three different
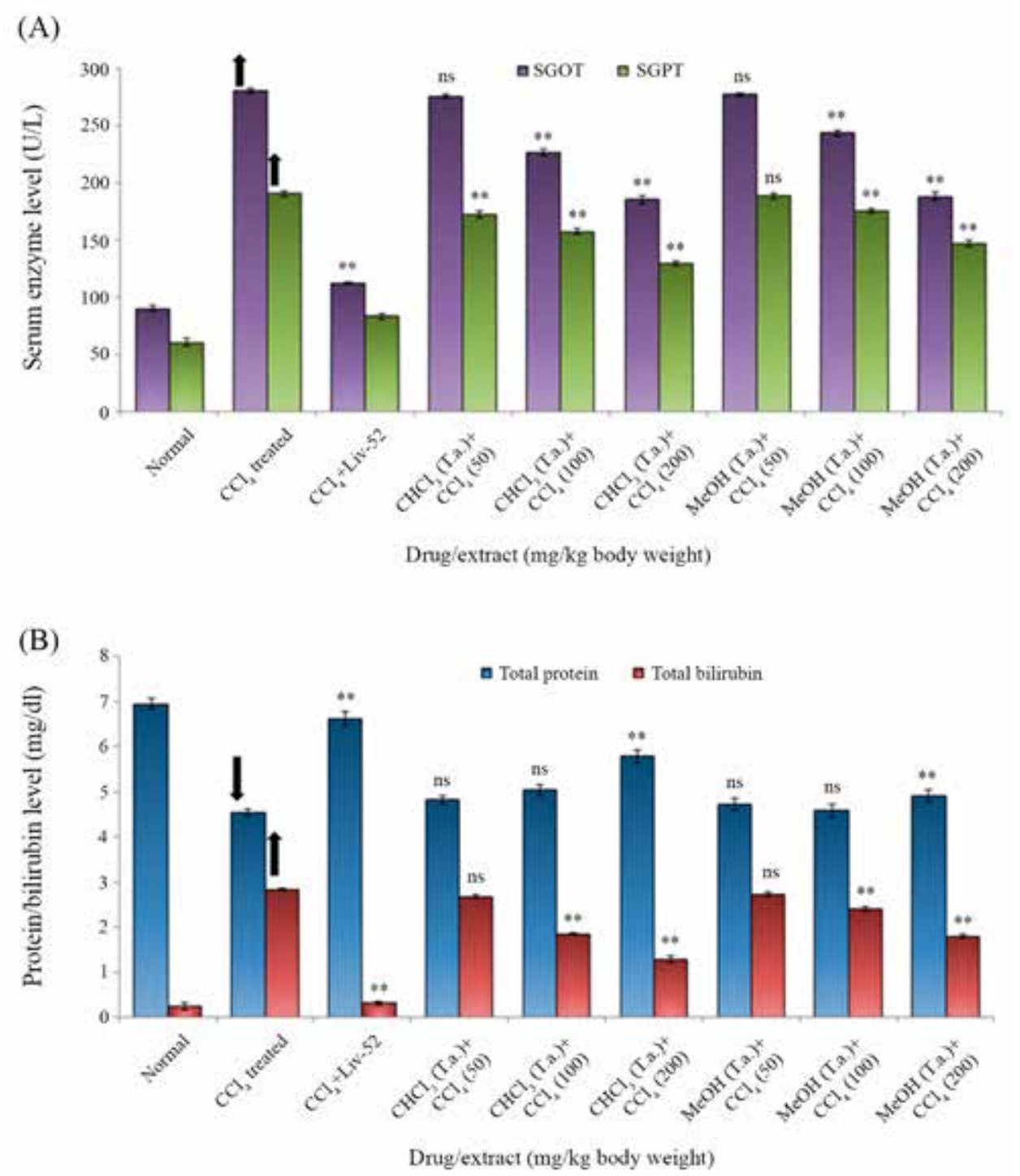

Fig. 2. Hepatoprotective activity of chloroform and methanolic extracts of dried shoots of T. aestivum in terms of evaluation of levels of serum enzymes (A) and protein/bilirubin (B). SGOT: Serum glutamic oxaloacetic transaminase; SGPT: Serum glutamic pyruvic transaminase; $\mathrm{CHCl}_{3}$ : Chloroform extract; MeOH: Methanol extract; T.a. $=$ Triticum aestivum. Values are mean \pm S.D. $\mathrm{p}$ value; $* * \mathrm{p}<0.01 ; \mathrm{ns}=$ nonsignificant; $\boldsymbol{\Delta}=$ Increase; $\boldsymbol{\nabla}=$ Decrease 
concentrations (50, 100 and $200 \mathrm{mg} / \mathrm{kg}$ b.w.) against the liver toxicity induced by $\mathrm{CCl}_{4}$ in albino Wistar rats. The group treated with $\mathrm{CCl}_{4}$ only, was more vulnerable to oxidative injury and thereby produced high liver marker enzymes in blood, whereas the group receiving the co-administration of extracts exhibited significant protection. As a result, the chloroform extract of dried shoots of $T$. aestivum significantly decreased the level of serum SGOT $(275.87 \pm 1.43,226.56 \pm 2.57,185.37 \pm 3.45 \mathrm{U} / \mathrm{L})$ and SGPT $(172.55 \pm 2.88,157.66 \pm 2.76,129.56 \pm 2.34 \mathrm{U} / \mathrm{L})$ at the concentration of 50,100 , and $200 \mathrm{mg} / \mathrm{kg}$ b.w., respectively. Also, the chloroform extract $(50,100$, and $200 \mathrm{mg} / \mathrm{kg}$ b.w.) significantly reduced the level of total bilirubin $(2.68 \pm 0.04$, $1.85 \pm 0.03,1.28 \pm 0.08 \mathrm{mg} / \mathrm{dL}$ ), while the level of total protein was elevated $(4.82 \pm 0.09,5.04 \pm 0.12,5.78 \pm 0.15 \mathrm{mg} / \mathrm{dL})$ (Fig. 2A, B). The results were compared with the standard (Liv-52) treated group along with $\mathrm{CCl}_{4}$ group, which showed a significant reduction in the elevated enzyme levels $(112.56 \pm 1.22 \mathrm{U} / \mathrm{L}, 83.56 \pm 2.45$ $\mathrm{U} / \mathrm{L})$, total bilirubin $(0.32 \pm 0.04 \mathrm{mg} / \mathrm{dL})$ and elevation in a level $(6.62 \pm 0.16 \mathrm{mg} / \mathrm{dL})$ of protein (Fig. 2A, B).

On the other hand, the methanolic extract of dried shoots of T. aestivum also reduced the level of SGOT $(277.12 \pm 1.23,243.76 \pm 2.65,188.34 \pm 3.12 \mathrm{U} / \mathrm{L})$ and SGPT $(188.72 \pm 2.54,175.55 \pm 1.76,147.22 \pm 3.38 \mathrm{U} / \mathrm{L})$ at the concentrations of 50 , 100 and $200 \mathrm{mg} / \mathrm{kg}$ b.w., respectively (Fig. 2A). Decreased level of total bilirubin was also evoked by the methanolic extract $(2.72 \pm 0.05,2.41 \pm 0.05,1.79 \pm 0.04 \mathrm{mg} / \mathrm{dL})$, while the increased level of total protein in the methanolic extract treated group was found to be $4.72 \pm 0.14,4.98 \pm 0.15,5.52 \pm 0.13 \mathrm{mg} / \mathrm{dL}$ at the extract concentrations of 50,100 and $200 \mathrm{mg} / \mathrm{kg}$ b.w., respectively (Fig. 2B). Interestingly, both the chloroform and methanolic extracts of dried shoots of $T$. aestivum displayed dose-dependent hepatoprotective activity with reduced SGOT and SGPT enzyme, as well as total bilirubin levels. The total protein level was enhanced in a concentration-gradient manner. At the tested concentrations of 100 and $200 \mathrm{mg} / \mathrm{mL}$, the chloroform and methanolic extracts of dried shoots of $T$. aestivum showed statistically significant differences $(\mathrm{p}<0.05)$ when compared with control groups (Fig. 2A, B).

\section{DISCUSSION}

Nowadays, there is a huge increase in using phenolic compounds in food and pharma industries, due to their potent ability to retard oxidative degradation of lipid, thereby improving the nutritional quality of a variety of foods as well as they show the multitude of pharmacological properties [3]. The mechanism of the cytotoxicity might be based on some reasons other than oxidative stress. Hence, various prospective epidemiological studies on individual and in the natural complex form of phytochemicals should be performed to investigate the effects on chronic diseases including cancer and cardiovascular diseases.

Previously, the chemoprotective ability of chlorophyll and its derivatives obtained from $T$. aestivum (wheat grass), has been determined using cell cultures and animal experimentation [15]. Chlorophyll is reported to show the antioxidant, anti-mutagen- 


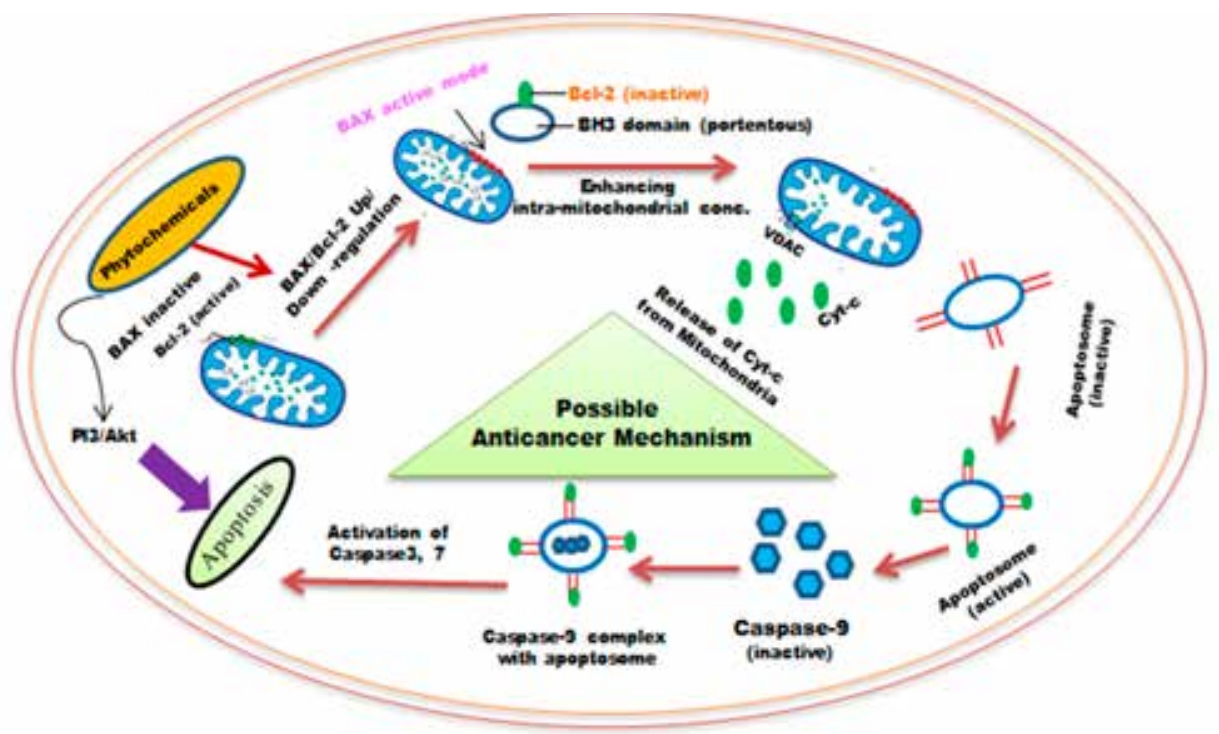

Fig. 3. Proposed apoptosis mode of action of bioactive phytochemicals of plant extracts. Bcl-2: B-cell lymphoma 2 protein, BAX: Bcl-2 associated X proteins, Cyt-c: Cytochrome C, VDAC: Voltage dependent anion channels, PI3/Akt: Phosphoinositide 3/protein kinase B pathway. Bioactive phytochemical chloroform extract of $T$. aestivum might up-regulate BAX protein in a dose-dependent manner while down-regulate the expression of Bcl-2 mRNA, which might be responsible causes and sustained elevation of calcium levels in mitochondria followed by cell apoptosis

ic and chemopreventive properties [3, 6, 15], which may be possible candidates of the anticancer activity of the chloroform extract of dried shoots of T. aestivum, as observed in this study.

Based on the present results, it can be stated that the chloroform extract of dried shoots of T. aestivum may act as an inducer of apoptosis and can exhibit anticancer activity via similar pathway. In anticancer pathway, Bcl-2 genes encode the Bcl-2 anti-apoptotic proteins acting as a checkpoint in the regulation of apoptosis. In addition, phytochemicals present in the chloroform extract of dried shoots of T. aestivum may lead to up-regulation and down-regulation of BAX and Bcl-2 proteins, which may substantially elevate the calcium level in the mitochondria (Fig. 3), suggesting the possibilities of the anticancer effect of $T$. aestivum derived phytochemicals. Although natural products have been reported to exhibit anticancer or anti-proliferative action very frequently, their various modes of actions have not been defined well to certain extended levels. However, based on the available research findings, we hypothesize and outline a possible molecular mechanism by which plant extracts or their active phytochemicals may exhibit anticancer effects (Fig. 3).

In this study, a significant increase of liver enzymes level in the plasma was observed after $\mathrm{CCl}_{4}$ administration, which was significantly lowered by the treatment with the chloroform and methanolic extracts of dried shoots of $T$. aestivum. The level 
of total protein was increased in the extracts of dried shoots of T. aestivum-treated group when compared to $\mathrm{CCl}_{4}$-treated group. Since the extracts of dried shoots of T. aestivum possessed rich amounts of bioactive substances including chlorophyll and carotene contents, the protective effects of chloroform and methanolic extracts of T. aestivum were observed against hepatotoxicity induced by $\mathrm{CCl}_{4}$. In addition, the hepatoprotective efficacy of chloroform and methanolic extracts of dried shoots of T. aestivum may be attributed to free radical scavenging activity of chlorophyll and carotene contents, as it was also confirmed previously [17]. The results obtained in the present study show that the chloroform and methanolic extracts of dried shoots of T. aestivum are promising sources of antiproliferative and hepatoprotective agents, and are rich in carotene and chlorophyll, which can act either individually or synergistically with a multitude of therapeutic potential. Further research strategies on isolation and identification of individual bioactive compounds from wheat grass (T. aestivum) and their efficacy on cellular and molecular levels need to be elaborated, in order to identify their exact action of mechanism.

\section{REFERENCES}

1. Adams, J. V., Slaght, K. S., Boogaard, M. A. (2004) An automated approach to lithcfield and Wilcoxon's evaluation of dose-effect experiments using the R package LW1949. Environ. Toxicol. Chem. 35, 3058-3061.

2. Adewusi, E. A., Afolayan, A. J. (2010) A review of natural products with hepatoprotective activity. J. Med. Plant Res. 4, 1318-1334.

3. Aneta, W., Jan, O. S., Renata, C. (2007) Antioxidant activity and phenolic compounds in 32 selected herbs. Food Chem. 105, 940-949.

4. Cervantes-Paz, B., Yahia, E. M., Ornelas-Paz, J. J., Victoria-Campos, C. I., Ibarra-Junquera, V, PerezMartinez, J. D., Escalante-Minakata, P. (2014) Antioxidant activity and content of chlorophylls and carotenoids in raw and heat-processed Jalapeño peppers at intermediate stages of ripening. Food Chem. 146, 188-196.

5. Chudapongse, N., Kamkhunthod, M., Poompachee, K. (2010) Effects of Phyllanthus urinaria extract on HepG2 cell viability and oxidative phosphorylation by isolated rat liver mitochondria. J. Ethnopharmacol. 130, 315-319.

6. Egner, P. A., Munoz, A., Kensler, T. W. (2003) Chemoprevention with chlorophyll in individuals exposed to dietary aflatoxin. Mut. Res. 524, 209-216.

7. Elliott, R. (2005) Mechanisms of genomic and non-genomic actions of carotenoids. Biochim. Biophys. Acta 1740, 147-154.

8. Ferruzzi, M. G., Blakeslee, J. (2007) Digestion, absorption, and cancer preventative activity of dietary chlorophyll derivatives. Nutri. Res. 27, 1-12.

9. Jayaraman, J. (2011) Estimation of Chlorophyll and Carotenoids. In Laboratory Manual in Biochemistry. New Age. Int. 1, 141-142.

10. Lee, R. H., Cho, J. H., Jeon, Y. J., Bang, W., Cho, J. J., Choi, N. J., Seo, K. S., Shim, J. H., Chae, J. I. (2015) Quercetin induces antiproliferative activity against human hepatocellular carcinoma (HepG2) cells by suppressing specificity protein 1 (Sp1). Drug Dev. Res. doi:10.1002/ddr.21235.

11. Maekawa, L., Lamping, R., Marcacci, M., Maekawa, M., Nassri, M., Koga, I. C. (2007) Antimicrobial activity of chlorophyll based solutions on Candida albicans and E. faecalis. RSBO 4, 36-40.

12. Malick, C. P., Singh, M. B. (1980) Plant Enzymology and Histoenzymology. Kalyani Publishers, New Delhi. 
13. Rana, S. V., Pal, R., Vaiphei, K., Ola, R. P., Singh, K. (2010) Hepatoprotection by carotenoids in isoniazid-rifampicin induced hepatic injury in rats. Biochem. Cell Biol. 88, 819-834.

14. Reddy, V. R., Bikshapathi, G., Reddy, K. M. (2014) Hepatoprotective activity of extract of Erythroxylum monogynum in albino rats. Int. J. Pure Appl. Biosci. 2, 58-62.

15. Sarkar, D., Sharma, A., Talukder, G. (1994) Chlorophyll and chlorophyllin as modifiers of genotoxic effects. Mut. Res. 318, 239-247.

16. Shenoy, K. A., Soumyaji, S. N., Bairy, K. L. (2001) Hepatoprotective effect of Ginkgo Biloba in carbon tetrachloride induced hepatic injury in rats. Indian J. Pharmacol. 33, 260-264.

17. Singh, S., Mehta, A., Mehta, P. (2011) Hepatoprotective activity of Cajanus cajan against carbon tetrachloride induced liver damage. Int. J. Pharm. Sci. 3, 146-147.

18. Singh, N., Verma, P., Pandey, B. R. (2012) Therapeutic potential of organic Triticum aestivum Linn. (wheat grass) in prevention and treatment of chronic diseases: An overview. Int. J. Pharm. Sci. Drug Res. 4, 10-14.

19. Tang, Z. Y., Ye, S. L., Liu, Y. K., Qin, L. X., Sun, H. C., Ye, Q. H., Wang, L., Zhou, J., Qiu, S. J., Li, Y. (2004) A decade's studies on metastasis of hepatocellular carcinoma. J. Cancer Res. Clin. Oncol. 130, 187-196.

20. Yin, Q. H., Yan, F. X., Zu, X. Y., Wu, Y. H., Wu, X. P., Liao, M. C., Deng, S. W., Yin, L. I., Zhuang, Y. Z. (2012) Anti-proliferative and pro-apoptotic effect of carvacrol on human hepatocellular carcinoma cell line HepG-2. Cytotechnology 64, 43-51. 